\title{
SURGICAL SITE INFECTIONS IN ADULTS PATIENTS UNDERGOING OF CLEAN AND CONTAMINATED SURGERIES AT A UNIVERSITY BRAZILIAN HOSPITAL
}

\author{
Maria de Lourdes Gonçalves SANTOS, Renata Rezende TEIXEIRA and Augusto DIOGO-FILHO
}

\begin{abstract}
Context - Surgical site infections are a risk inherent to surgical procedures, especially after digestive surgeries. They occur up to 30 days after surgery, or up to a year later if a prosthesis is implanted. The Surgical-site Infection Risk Index (SIRI), NISS (National Nosocomial Infection Surveillance) methodology, is a method to evaluate the risk of surgical site infections, which takes into account the potential contamination of the surgery, the patient's health status and surgery duration. Objectives - To evaluate the correlation between the surgical-site infection risk index score on the 1st day postoperatively, and the development of surgical site infection up to 30 days postoperatively. Methods - The postoperative surgical site infections (NNIS) was evaluated by following-up in hospital and as an outpatient. The patients followed prospectively were those submitted to elective surgeries, clean (hernioplasties) or contaminated (colorretal), performed by conventional approach at a university hospital, during the period from June 2007 to August 2008. The mean age of the patients was 55.5 years, $133(65.5 \%)$ male; $120(59.1 \%)$ submitted to clean surgeries and $83(40.9 \%)$ contaminated. Results - The global index of surgical site infections was $10.3 \% ; 10(8.3 \%)$ in clean procedures and $111(3.2 \%)$ in contaminated ones. Four (19.1\%) of the surgical site infections were diagnosed at the time of hospitalization and 17 $(80.9 \%)$ at post-discharge follow-up. Twelve $(57.1 \%)$ of the surgical site infections were superficial, $2(9.5 \%)$ deep and $7(33.3 \%)$ at a specific site. Of these, $5(6.6 \%)$ were in patients classified as SIRI 0 (76); $9(15 \%)$ for SIRI 1 (60); 5 (9.1\%) for SIRI 2 (55) and 2 (16.7\%) for SIRI 3. Conclusion - The global index of surgical site infections and its incidence among contaminated procedures are within the expected limits. On the other hand according to SIRI, the surgical site infection indexes are above the expected standards both for the clean and for the contaminated procedures.
\end{abstract}

HEADINGS - Surgical wound infection. Gastrointestinal tract, surgery.

\section{INTRODUCTION}

According to the Brazilian Ministry of Health, hospital infection is an infection acquired after admission of the patient to hospital, and its onset during the hospital stay or after discharge. It can be related to hospitalization or to hospital procedures ${ }^{(5)}$.

The hospital infection rates vary according to the type of surveillance used, and with the degree of hospital complexity. They are generally higher in the large hospitals and teaching hospitals. The latter are often a reference in their regions and receive high complexity patients. Furthermore, since it is a teaching hospital, there are students in training and more people involved in the procedures ${ }^{(22)}$.

Surgical site infection (SSI), which accounts for $14 \%$ to $16 \%$ of all hospital infections ${ }^{(8,10,19)}$, is important because it presents high rates of morbidity and mortality, causes losses to the patients, such as keeping them away from their family and from professional activities, besides

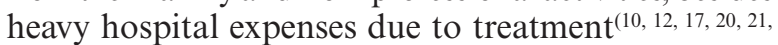

${ }^{24)}$. It is a risk inherent to the surgical procedure, often acknowledged as a frequent complication, especially in digestive system procedures. Generally, it is manifested by the presence of local erythema, edema, heat, color, temperature and/or dehiscence and purulent secretion at the surgical site ${ }^{(11,21)}$.

Most SSI occur between 4 and 6 days after the procedure ${ }^{(20)}$. However, according to the CDC (Center for Disease Control) in Atlanta, GA, USA, $98 \%$ of the SSI can present up to 30 days after surgery, or even a year later when a prosthesis has been implanted ${ }^{(3)}$. Therefore, it is important to follow-up the patients after discharge from hospital, since after the hospitalization period, the rate of diagnosis of SSI can range from $12 \%$ to $84 \%{ }^{(20)}$.

The SSI can be classified as superficial if they involve only the skin or subcutaneous cell tissue at the site of the incision; deep when they affect more internal structures of the abdominal wall below the fascia, including the muscle layer; and specific site when they also involve the abdominal cavity and the

Universidade Federal de Uberlândia, MG, Brazil

Correspondence: Dr. Augusto Diogo Filho - Avenida Pará, 1270 - Bairro Umuarama - 38405-320 - Uberlândia, MG, Brasil. E-mail: diogofilho@netsite.com.br 
space between the organs that were manipulated during the surgical procedure ${ }^{(3,7,13,17,23)}$.

Some classifications are used to identify risk groups, factors and procedures, and thus to adapt the results to more reliable numbers on rates of infections. These measures can reduce the SSI rates by $35 \%$ to $50 \%$ of those normally found ${ }^{(10)}$. One of them is to calculate the Surgical-site Infection Risk Index (SIRI) which adopts the NNIS (National Nosocomial Infection Surveillance) methodology. This model scores: contaminated/infected surgery, duration of surgery over the expected time in $75 \%$ of similar procedures, and an ASA (American Society of Anesthesiologists) of 3, 4 or 5. The maximum score of 3 indicates a higher risk of infection at the surgical site. On the other hand, 0 score is low risk, and scores 1 and 2 , intermediate risk $^{(6,16)}$.

The purpose of this study was to evaluate the evolution of the surgical site for clean and contaminated procedures, as to the development of an infection based on the SIRI score, analyzed during the postoperative period, at 24 hours, and up to 30 days.

\section{METHODS}

Patients submitted to clean or contaminated elective surgeries, performed by conventional approach at Hospital de Clínicas da Universidade Federal de Uberlândia, MG, Brazil, between June 2007 and October 2008 were followed prospectively. Patients of both sexes, aged over 18 years participated in the research. The study was approved by the committee of ethics in research at Universidade Federal de Uberlândia, protocol no. 128/07. A free and informed letter of consent was applied to all who gave their permission to participate in the study.

The SIRI score (0-3), utilized by the NNIS methodology (Table 1) was used to stratify the risk of surgical infection.

TABLE 1. Surgical site infection risk index (SIRI) according to the $\mathrm{NNIS}^{(9)}$ methodology

\begin{tabular}{ll}
\hline Risk factor & Score \\
\hline Surgical classification & \\
\hline Clean & 0 \\
Contaminated & 1 \\
\hline ASA classification & 0 \\
\hline 1 or 2 & 1 \\
3,4 or 5 & \\
\hline Duration of surgery & 0 \\
\hline$<75 \%$ of similar procedures & 1 \\
$>75 \%$ of similar procedures &
\end{tabular}

Among the clean surgeries, only hernioplasties with an indication for elective surgery were evaluated, in which the hollow viscera were not opened, and the aseptic technique was followed completely. For contaminated surgeries, elective colorectal surgeries were evaluated, with the mechanical cleaning and preparation of the colon during the preoperative period. As to the overall conditions of the patient, the ASA classification $^{(10)}$ was adopted, evaluated by the anesthetist.
Procedures that overstepped the time spent in $75 \%$ of similar procedures, 3 hours for colorectal surgeries and 2 hours for hernioplasties ${ }^{(6)}$ were considered a prolonged duration of surgery.

Adding up the scores obtained for each variable presented in Table 1, a SIRI between 0 and 3 was obtained.

The beginning, time and type of antibiotic used were analyzed.

The surgical team was composed of coloproctologist or general surgeon with experience exceeding 10 years and residents in general surgery. The patients were followed by the medical team with notes written on the respective records during the stay in hospital. The data were complemented from the return visits as outpatients up to 30 days after surgery. Cases that presented a flush or purulent secretion with surgical or spontaneous drainage, or the detection of a collection located in deep planes or a specific site by imaging methods (ultrasound, computed tomography) ${ }^{(2,}$ ${ }^{7)}$, with or without identifying organisms were considered surgical site infections.

\section{RESULTS}

The mean age of the 203 patients followed was 55.5 years, $133(65.5 \%)$ male; $120(59.1 \%)$ submitted to clean surgeries and $48(40.9 \%)$ contaminated.

Among the hernioplasties, 85 (70.9\%) were inguinal, 27 $(22.5 \%)$ incisional, $7(5.8 \%)$ umbilical, and $1(0.8 \%)$ femoral. Of the contaminated procedures, rectosigmoidectomy was $51(61.4 \%)$ of the cases, followed by right colectomy (8) $9.6 \%$ and abdomino-perineal amputation $8(9.6 \%)$, left colectomy $5(6 \%)$, total colectomy and transversectomy $4(4.8 \%)$, proctocolectomy $2(2.4 \%)$ and reconstruction of intestinal transit $1(1.2 \%)$.

The global index of SSI (clean and contaminated) was $10.3 \%, 10(8.3 \%)$ for the clean procedures, and 11 $(13.2 \%)$ for the contaminated ones. Of the SSI, $4(19.1 \%)$ were diagnosed during hospitalization and $17(80.9 \%)$ at post-discharge follow-up (Figure 1). Considering only the infections diagnosed during hospitalization, the index found was $1.9 \%$ (4), $0 \%$ for clean surgeries, and $4.8 \%$ (4) for the contaminated surgeries.

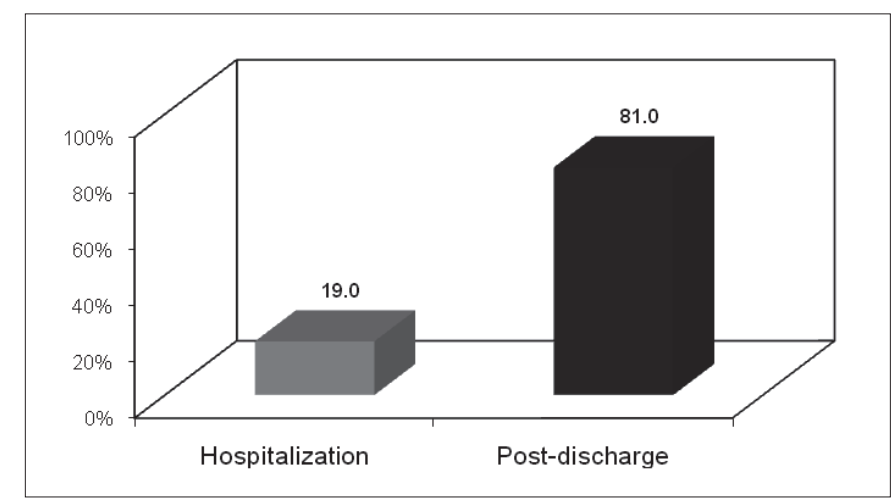

FIGURE 1. - Surgical site infection indexes at the time of diagnosis 
Of the SSI, $12(57.1 \%)$ were classified as superficial, 2 $(9.5 \%)$ as deep, and $7(33.3 \%)$ as site-specific.

The SSIs, including clean and contaminated surgeries, according to the SIRI classification, were distributed as follows: $5(6.6 \%)$ for patients classified as SIRI $0(76) ; 9(15 \%)$ for those who presented only a single risk factor, considered SIRI $1(60) ; 5(9.1 \%)$ for SIRI $2(55)$, and $2(16.7 \%)$ for the SIRI 3 (12) (Figure 2).

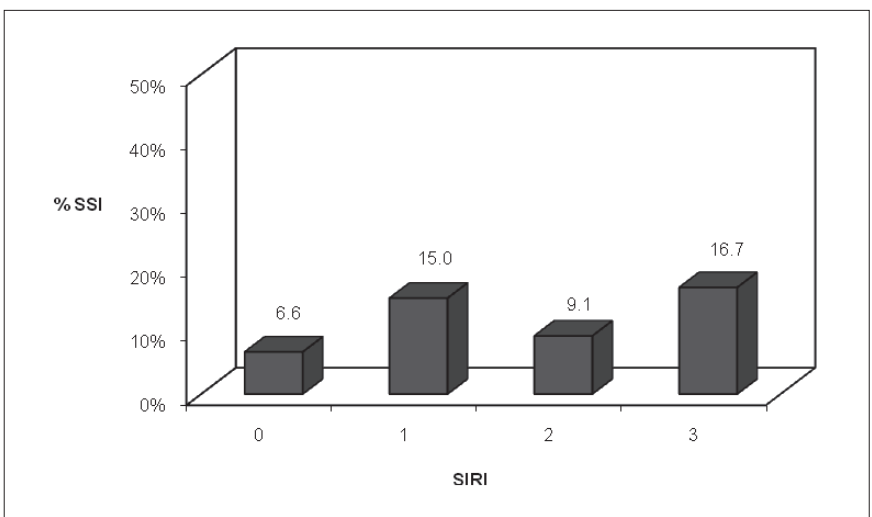

FIGURE 2. Relationship between SIRI and surgical site infection occurrence, including clean and contaminated surgeries

Considering only the clean surgeries, $5(6.6 \%)$ of the 76 patients classified as SIRI 0 presented infection, $4(10.5 \%)$ of the 38 patients classified as SIRI 1 and $1(16.7 \%)$ of the 6 patients classified as SIRI 2 had SSI. By definition, no patient submitted to clean surgery can be classified as SIRI 3 (Figure 3).

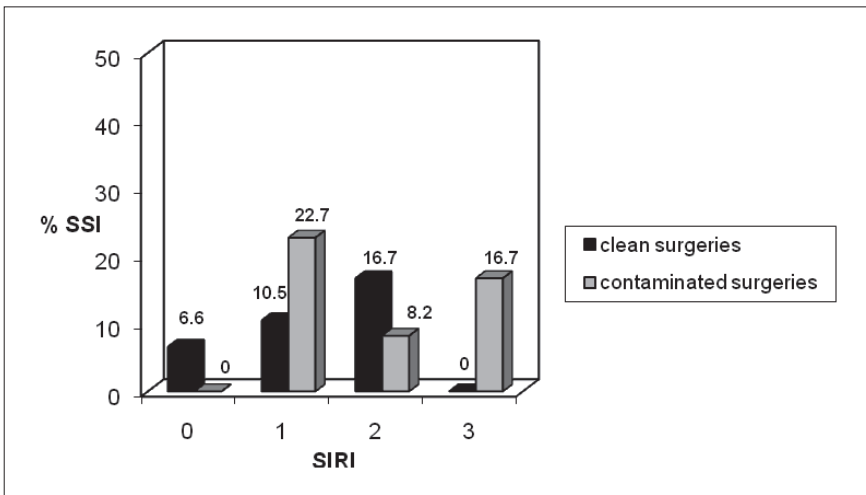

FIGURE 3. Relationship between SIRI and surgical site infection occurrence in clean and contaminated procedures

Considering the contaminated surgeries, of 22 SIRI 1 patients, $5(22.7 \%)$ developed SSI and presented a potential for surgical contamination as the single risk factor. Of 49 SIRI 2 patients, $4(8.2 \%)$ developed SSI; of 12 SIRI 3 patients $2(16.7 \%)$ presented SSI (Figure 3).
In the clean procedures the prophylactic antibiotic was given to $101(84.2 \%)$ of the patients, and cephazolin was used in $100 \%$ of the cases, and at the time of anesthetic in $94(93.3 \%)$ of the cases. The mean time of use was 1.5 days. The polypropylene screen was used in $98(81.7 \%)$ of the patients submitted to hernioplasty, $85(86.7 \%)$ of whom received prophylactic antibiotic. Of the $22(18 \%)$ patients who did not use the prosthesis, $16(72 \%)$ received prophylactic antibiotics. On the other hand, in contaminated procedures, prophylactic antibiotics were used in $82(98.7 \%)$ of the patients, of whom $68(83 \%)$ used the combination of ceftriaxone and metronidazole, $66(80.5 \%)$ began at the time of anesthetic induction and the mean time of use was 3.6 days. In the other patients, the antibiotic was administered after surgery began.

In the 101 patients submitted to clean procedures who used antibiotics, the SSI rate was $6.9 \%$ (7). On the other hand for those submitted to contaminated procedures who used an antibiotic (82 patients), the rate of infection was $12.2 \%$ (10) (Figure 4).

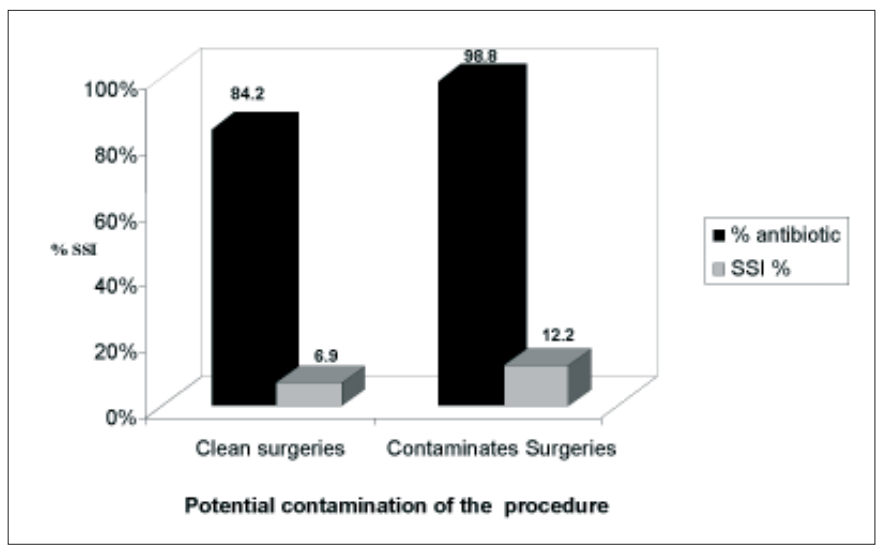

FIGURE 4. Use of prophylactic antibiotics in clean and contaminated procedures and surgical site infection occurrence in each group

\section{DISCUSSION}

The occurrence of surgical site infection notified only during hospitalization does not supply reliable data and underestimates the true rates of postoperative infection. There are several methods to perform post-discharge surveillance of SSI. The choice of the ideal form varies from one institution to another. Each of them must use the method which is compatible with their resources, structure and the profile of the patients treated. Active surveillance through outpatient services, despite the problems encountered, is the most effective method to obtain reliable data on the incidence of $\mathrm{SSI}^{(20)}$.

In this study $80.9 \%$ of the infections were diagnosed after discharge, through outpatient follow-up or by visits to the emergency room of the hospital in the cases when some event occurred. This information agrees with other data found in the literature, in which the SSI rate of this period may reach $84 \%{ }^{(20)}$. The results obtained show the importance of following these patients for at least 30 days, since most of 
the cases would not have been notified if the follow-up were limited to their hospitalization period.

The degree of association between SIRI and the rate of SSI found in this study are different from the results presented by Culver et al. ${ }^{(6)}$ and Freitas et al. ${ }^{(10)}$, which may be explained by the fact that those authors limited the follow-up to hospitalization. Considering only the infections diagnosed during the period in hospital, this study found results similar to those described by the above-mentioned authors, illustrating the fact that under notification of SSI masks reality.

The rates of infection in contaminated procedures $(13.2 \%)$ agreed with previous studies ${ }^{(7,19)}$. The SSI rates found for clean surgeries $(8.3 \%)$ go beyond the values considered acceptable by the literature $(5 \%)$. A previous study performed by De Conti et al. ${ }^{(7)}$ in the same Service, in 2001, observed the same rate of SSI for clean surgeries. A few studies show that the surgeon's experience may influence the rates of postoperative complications, including $\mathrm{SSI}^{(3)}$, above all in clean surgeries, for which high rates of infection may really mean that the aseptic technique has not been obeyed.

After stratification of the patients for the risk of developing SSI by applying SIRI, the results showed SSI rates above the expected levels ${ }^{(3,7)}$, both for clean and for contaminated procedures. It must be taken into account that this study was performed at a teaching hospital, which has professionals at different levels of training in the medical residency programs. These characteristics may contribute to higher rates of infection, since they require the involvement of more professionals in each procedure ${ }^{(3)}$.

There is a correlation between the progressive degrees of SIRI and the rates of SSI. The greater the degree of SIRI, the greater the probability of SSI, but our study found a high incidence of infection in a group one which indicate the occurrence of technical problems in carrying surgical or carelessness of the team since the SIRI correcting factors as health status of the patient during surgery, prolonged surgical duration and degree of contamination.

The high rates of SSI found in this study reinforce the importance of implementing effective surveillance programs to fight this type of postoperative complication. The most important factors in postoperative infection include the general state of the patient, appropriate surgical technique with good hemostasis, careful handling of the tissues, absence of dead space, and administering prophylactic antibiotic ${ }^{(2)}$.
Currently, the use of prophylactic antibiotics is recommended in contaminated procedures. In clean surgeries it is indicated when prostheses are implanted, or in patients with risk factors (obesity, diabetes, immunosuppression, etc.) and also in cases in which an infection could lead to catastrophic results, such as neurosurgical procedures ${ }^{(4,17,18)}$. However, there are controversies about the use of antibiotics in clean surgeries, even with polypropylene prostheses, such as inguinal hernias ${ }^{(1,}$ 2). The procedures considered dirty or infected deserve therapeutic use, i.e. for an extended period ${ }^{(15)}$.

It was observed that $84.2 \%$ of the patients submitted to clean surgery and $98.7 \%$ of the contaminated ones, used prophylactic antibiotics on average for a slightly longer time than recommended in the literature, however the SSI rates were above the expected, even using SIRI.

It is known that the antimicrobials should be used carefully in order to avoid selecting multiresistant pathogens ${ }^{(4,9,17,24)}$. The agents most commonly involved in the development of infection in the clean procedures are from the patient's normal microflora, generally S. aureus and Coagulase-negative S, while in the contaminated procedures the infection is generally polymicrobial $^{(3)}$. The antimiocrobials used in this study were in accordance with the probable microflora of the surgical area involved. The antibiotic should be administered about half an hour to one hour before the incision, so that at the beginning of the procedure it will achieve minimum inhibitory concentration in the tissue ${ }^{(15)}$. It is unnecessary to use it for a long time, after 24 hours, during the postoperative period, and recent studies show that it does not improve the rates of infection ${ }^{(7,15)}$.

Although the study was performed at a university hospital, with the active presence of the Hospital Infection Control Committee and Antibiotics Committee, and in-house publication of standards and periodical meetings with the medical services ${ }^{(1)}$, the rates of infection and the duration of antibiotic use were above the recommended level.

\section{CONCLUSION}

The use of postoperative SIRI proposed by the NNIS methodology supplies more reliable data on the occurrence of postsurgical infection despite of antibiotic use. Its association with postoperative follow-up brings the SSI results closer to the real values of this complication. 
Santos MLG, Teixeira RR, Diogo-Filho A. Infecção do sítio cirúrgico em pacientes adultos submetidos a cirurgias limpas e contaminadas em hospital universitário brasileiro. Arq Gastroenterol. 2010;47(4):383-7.

RESUMO - Contexto - As infecções do sítio cirúrgico constituem risco inerente ao ato operatório, principalmente após cirurgias digestivas. Ocorrem até 30 dias após a cirurgia, ou até 1 ano, se houver implante de prótese. O índice de risco de infecção cirúrgica (IRIC), metodologia NISS (National Nosocomial Infection Surveillance), é um método de avaliação do risco de infecções do sítio cirúrgico que considera o potencial de contaminação da cirurgia, o estado de saúde do paciente e o tempo cirúrgico. Objetivo - Avaliar a correlação entre a pontuação IRIC no primeiro dia de pós-operatório e o desenvolvimento da infecção do sítio cirúrgico até 30 dias de pós-operatório. Avaliou-se a infecção do sítio cirúrgico (NNIS) pós-operatória através de seguimento à internação e em ambiente de ambulatório. Métodos - Foram acompanhados, prospectivamente, pacientes submetidos a cirurgias eletivas, limpas ou contaminadas, realizadas por via convencional em hospital universitário no período de junho de 2007 a agosto de 2008 . A média de idade dos pacientes foi de 55,5 anos, $133(65,5 \%)$ do sexo masculino; $120(59,1 \%)$ submetidos a cirurgias limpas e 83 (40,9\%) contaminadas. O índice global de infecções do sítio cirúrgico foi de 10,3\%: 10 (8,3\%) em procedimentos limpos e 11 (13,2\%) em contaminados. Quatro (19,1\%) das infecções do sítio cirúrgico foram diagnosticadas na internação e 17 (80,9\%), no seguimento pós-alta. Doze (57,1\%) das infecções do sítio cirúrgico foram superficiais: $2(9,5 \%)$ profundas e $7(33,3 \%)$ de sítio específico. Destas, $5(6,6 \%)$ em pacientes classificados como IRIC 0 (76); 9 (15\%) para IRIC 1 (60); 5 (9,1\%) para IRIC 2 (55) e $2(16,7 \%)$ (2) para IRIC 3. Conclusãa - O índice global de infecções do sítio cirúrgico e sua incidência entre procedimentos contaminados estão dentro dos limites esperados. Avaliados pelo IRIC, os índices de infecções do sítio cirúrgico estão acima dos padrões esperados tanto para os procedimentos limpos quanto para os contaminados.

DESCRITORES - Infecção da ferida operatória. Trato gastrointestinal, cirurgia

\section{REFERENCES}

1. Anderson DJ, Sexton DJ, Kanafani ZA, Auten G, Kaye KS. Severe surgical site in community hospitals: epidemiology, key procedures, and changing prevalence of methicilin-resistante Staphylococcus aureus. Infect Control Hosp Epidemiol. 2007;28:1047-53.

2. Anderson DJ, Sexton DJ. Control measures to prevent surgical site infection [Internet]. [cited 2009 Sept 23]. Available from: http://www.uptodate.com.

3. Anderson DJ, Sexton DJ. Epidemiology and pathogenesis of and risk factors for surgical site infection [Internet]. [cited 2009 Sept 23]. Available from: http://www. uptodate.com.

4. Bell DM. Promoting appropriate antimicrobial drug use: perspective from the Centers for Disease Control and Prevention. Clin Infect Dis. 2001;33:S245-50.

5. Chor D, Klein CH, Marzochi KBF. Infecção hospitalar: comparação entre dois métodos de vigilância epidemiológica. Cad Saúde Pública. 1990:6:201-17.

6. Culver DH, Horan TC, Gaynes RP, Martone WJ, Jarvis WR, Emori TG, Banerjee SN, Edwards JR, Tolson JS, Henderson TS, Hughes JM; National Nosocomial Infections Surveillance System. Surgical wound infection rates by wound class, operative procedure, and patient risk index. National Nosocomial Infections Surveillance System. Am J Med. 1991;91(3B):152S-7S

7. De Conti DO, Diogo-Filho A, Prado FA, Pereira RAO, Faria LOA, Carrijo EM Avaliação das infecções do sítio cirúrgico em pacientes operados numa enfermaria de cirurgia geral no HC-UFU, no período de janeiro a junho de 2000 . Biosci J. 2001;17:193-204.

8. de Oliveira AC, Ciosak SI, Ferraz EM, Grinbaum RS. Surgical site infection in patients submitted to digestive surgery: risk prediction and the NNIS risk index. Am J Infect Control. 2006;34:201-7.

9. Eriksen HM, Iversen BG, Aavitsland P. Prevalence of nosocomial infections and use of antibiotics in long-term care facilities in Norway 2002 and 2003. J Hosp Infect. 2004;57:316-20.

10. Freitas PF, Campos ML, Cipriano ZM. Aplicabilidade do Índice de Risco do Sistema NNIS na predição da incidência de Infecção do Sítio Cirúrgico (ISC) em um hospital universitário do sul do Brasil. Rev Assoc Med Bras. 2000;46:359-62.

11. Garibaldi RA, Cushing D, Lerer T. Risk factors for postoperative infection. Am J Med. 1991;91(3B):158S-63S.

12. Hollenbeak CS, Lave JR, Zeddies T, Pei Y, Roland CE, Sun EF. Factors associated with risk of surgical wound infections. Am J Med Qual. 2006;21:29S-34S.
13. Horan TC, Gaynes RP, Martone WJ, Jarvis WR, Emori TG. CDC definitions of nosocomial surgical site infections, 1992: a modification of CDC definitions of surgical wound infections. Infect Control Hosp Epidemiol. 1992;13:606-8.

14. Jorge MT, Fontes AMS, Burjaili B. Guia para profilaxia com antimicrobiano em cirurgia. Uberlândia, MG: Hospital de Clínicas da Universidade Federal de Uberlândia, Serviço de Controle de Infecção Hospitalar; 2007.

15. Karamanis E, Peppas G, Alexiou VG, Falagas ME. World Wide Web resources on prevention and treatment of postoperative infection. Am J Surg. 2008;196: 307-10.

16. Knight R, Charbonnneau P, Ratzer E, Zeren F, Haun W, Clark J. Prophylactic antibiotics are not indicated in clean general surgery cases. Am J Surg. 2001;182:6826.

17. Malone DL, Genuit T, Tracy JK, Gannon C, Napolitano LM. Surgical site infections: reanalysis of risk factors. J Surg Res. 2002;103:89-95.

18. Mangram AJ, Horan TC, Pearson ML, Silver LC, Jarvis WR. Guideline for prevention of surgical site infection, 1999. Hospital Infection Control Practices Advisory Committee. Infect Control Hosp Epidemiol. 1999;20:250-78.

19. Medeiros AC, Neto TA, Filho AMD, Pinto Jr FEL, Uchôa RAC; Carvalho MR. Infecção hospitalar em pacientes cirúrgicos de hospital universitário. Acta Cir Bras. 2003;18:15-8.

20. Oliveira AC, Martins MA, Martinho GH, Clemente WT, Lacerda RA. Estudo comparativo do diagnóstico da infecção do sítio cirúrgico durante e após a internação. Rev Saude Publica. 2002;36:717-22.

21. Oliveira AC, Ciosak SI. Infecção de sitio cirúrgico no seguimento pós-alta: impacto na incidência e avaliação dos métodos utilizados. Rev Esc Enferm USP. 2004;38:379-85.

22. Pereira MS, Moriya TM, Gir E. Infecção hospitalar nos hospitais escola: uma análise sobre seu controle. Rev Lat Am Enfermagem. 1996;4:145-62.

23. Petherick ES, Dalton JE, Moore PJ, Cullum N. Methods for identifying surgical wound infection after discharge from hospital: a systematic review [Internet]. [cited 2009 Febr 5]. Available from: http://www.biomedcentral. com/1471-2334/6/170.

24. Webb AL, Flagg RL Fink AS. Reducing surgical site infections through a multidisciplinary computerized process for preoperative prophylactic antibiotic administration. Am J Surg. 2006;192:663-8.

Received 24/2/2010 Accepted 22/6/2010. 